\title{
The efficiency of the different elements of spring barley growing organic technology in the conditions the eastern steppe of Ukraine
}

\author{
Vinyukov Alexandr Alexandrovitch - Bondareva Olga Braunovna - Vinyukova Olga Borisovna \\ National Academy of Agricultural Sciences, Donetsk State Agricultural Science Station, Donetsk, Ukraine \\ alex.agronomist@mail.ru
}

SUMMARY

The effectiveness the use of new nutrient complexes is studied. It is set that a combination of nutrient complexes with organic and organic-
mineral nutrition background promotes to good growth and development of plants during the growing season, provides the best parameters
f crop yield structure and the crop yield and economic efficiency of spring barley cultivation in the condition of the Eastern Steppe of Ukraine.

Keywords: nutrient complex, nutrition background, spring barley, crop yield, economic efficiency

\section{INTRODUCTION}

Throughout its humankind history has sought to improvement of agricultural production, including plant growing. The purpose of the improvement was possibility of obtaining more of products from a smaller area of farmland.

Starting with the second half of the twentieth century, the agricultural producers began intensive use of fertilizers. This allowed access to intensive grain production. The use of fertilizers contributed to increasing crop yield by 20-25\% (Бурбела 1995). The balance of nutrients in the soil was maintained through industrially produced agrochemicals.

Beginning with the 60's the development of the chemical industry allowed to attach to mineral fertilizers pesticides that are allowed to successfully deal with pests, diseases and weeds. All of these factors significant increase crop yield the largest share of which belonged to the application of chemicals (Лихочвор 2004).

Production of relatively cheap fertilizers and pesticides has led to sharp changes in traditional technologies. Crop rotations have been violated the use of organic fertilizers were abandoned. Breeding new varieties was aimed at their intensification, the need for the fullest use of mineral fertilizers. An urgent problem of environmental pollution and the crop products of agricultural chemicals remain (Тараріко 1999).

The economic crisis with end of the $20^{\text {th }}$ century to beginning of $21^{\text {th }}$ century the most blow to agriculture. The desire of farmers to obtain stable economic income completely forced them to abandon the classical crop rotation, and in some cases only cultivate monoculture (Olofsson 1993, Jankowski et al. 2015). Significant economic costs of full tillage farmers forced move to minimum tillage or to system No-till. Also the percentage of use of mineral fertilizers greatly decreased and organic fertilizers entirely "passed into history." Only the use of pesticides is not reduced, which finally led to the destruction of the soil microflora, as well as useful the entomofauna (Ковырялов 1989).

This led to the search for organic farming systems that would not only reduce the chemical load on the agrocenosis but also cheaper agricultural production (Shanahan et al. 1985, Sieling et al. 1999). In the last years, more and more attention is given biological farming systems that are based on the ecologization and biologization intensification processes. Biologization is maximum coordination of technology with biological requirements of the crops and varieties. Everything is done to create the best conditions for the development of the main object of technology - plants (Qin et al. 2004, Cociu 2012, Rácz et al. 2015).

The main features of organic or alternative agriculture are the proper use of crop rotation, organic fertilizers, plant residues, green manures, straw, etc., complete (or partial) rejection of the use of agrochemicals.

At this stage development of agriculture none of the proposed science biological technology cannot fully integrated into agricultural production. To this there are lot of reasons. First of all - it's agricultural economic instability and lack of legislative regulations of pricing on organic products (Кисіль 1997).

Therefore, research scientists Donetsk agricultural science station direction to development of organic technologies and the introduction of some organic elements that are able to be combined with other technologies. Such elements can reduce the use of mineral fertilizers and pesticides while increasing qualitative and quantitative indicators of crop production.

\section{MATERIAL AND METHODS}

Study was conducted of laboratory and field methods. Repeated experiments with 3-fold. Systematic placement plots.

Soil - humus black soil ordinary, clayey loam. The gross contents of main nutrients: $\mathrm{N} 0.28-0.31 \%, \mathrm{P}_{2} \mathrm{O}_{5}$ $0.16-0.18 \%, \mathrm{~K}_{2} \mathrm{O} 1.8-2.0 \%$, content of humus in the plow layer $4.5 \%$, pH 6.9 .

Sown area of plot of $88.2 \mathrm{~m}^{2}$. Mineral and organic fertilizers were used according to the scheme of the experiment. Seed treatment performed the day before sowing. Crop spraying performed in the tillering stage and in the beginning earing stage. Control - seed treatment and crop water spraying.

Harvest data were converted to standard moisture with pollution considering the grain mass. In experiments performed phenology, agrometeorological observations was determined the structure of the crop. Statistical analysis of yield data was carried out by B. Dospehov method (Доспехов 1985). 


\section{RESULTS AND DISCUSSION}

In the experiment, we studied the effect of new nutrient complexes with using three of backgrounds nutrition by grown variety Shidniy spring barley. The first nutrient complex: seed treatment preparation rost-forte in a mixture of aminoacids complex and set of biologics, crop spraying in the tillering and earing stages of a mixture preparations rost-concentrate 15.7.7. + aminoacids complex + helatyn + microbiological system for protection of plants against pests and diseases. The second nutrient complex: seed treatment liquid biofertilizer aydar in a mixture of complex biologics and crop spraying at tillering and earing stages mixture of biofertilizer aydar and microbiological system for additional stimulation of plants and protect them from diseases and pests.

At the tillering stage of plant selection was performed with $1 \mathrm{~m}^{2}$ of each variant for the analysis the cultures at this stage (Table 1).

On the mineral nutrition background best biometric parameters were obtained with biological crop protection and new nutrient complexes. The highest coefficient of tillering was when used the second complex (3.76) and the coefficient of nodal roots by the seed treatment and crop spraying microbiological preparations (1.47).

On the organic-mineral nutrition background the most increase of biometric parameters was obtained when used the first nutrient complex.

On the organic background increase tillering coefficient was obtained when using only the first nutrient complex.
Increasing the coefficient of nodal roots compared with control was obtained in all variants but this index was highest when used microbiological preparations.

When compared three backgrounds together, it was found that a large impact on biometric indicators provide mineral and organic-mineral backgrounds.

None of the variants presented did not provide for an increase in total coefficient tillering compared to control at the background of mineral nutrition (Table 2).

What about coefficient of productive tillering, all variants that have been studied influenced to increase of this index compared with the control. The biggest impact has provided the use of microbiological preparations to stimulate growth processes and the protection of plants against pests and diseases.

On the organic-mineral nutrition background in the event of total tillering coefficient was recorded a similar situation as in the previous background. The highest coefficient of productive tillering was obtained by the use of chemical crop protection (1.77).

On the organic nutrition background of using variants that were studied, there was an increase in the coefficients of both general and productive tillering compared with controls. The greatest coefficient of general tillering was obtained using the first nutrient complex (2.45) and the highest coefficient of productive tillering - then using of the second nutrient complex (1.46).

When comparing the three backgrounds nutrition can be concluded that the best the potentialities preparations were obtained by using an organic background. That is on the organic nutrition background were obtain the highest coefficients of the general and productive tillering in comparison with the control.

Table 1.

The development of spring barley plants at tillering stage depending on the nutrient complex and nutrition background (2012-2014)

\begin{tabular}{|c|c|c|c|c|c|}
\hline Variant & $\begin{array}{l}\text { Number of } \\
\text { stems } \\
\left(\text { pc. per } \mathrm{m}^{2}\right)\end{array}$ & $\begin{array}{l}\text { Number of } \\
\text { nodal roots } \\
\left(\text { pc. per } \mathrm{m}^{2}\right) \\
\end{array}$ & $\begin{array}{l}\text { Coefficient of } \\
\text { tillering }\end{array}$ & $\begin{array}{c}\text { Coefficient of } \\
\text { nodal roots }\end{array}$ & $\begin{array}{l}\text { Plant height } \\
(\mathrm{cm})\end{array}$ \\
\hline & \multicolumn{5}{|c|}{ Nutrition background $1-\mathrm{N}_{30} \mathrm{P}_{30} \mathrm{~K}_{30}$} \\
\hline 1. Control & 1398 & 417 & 3.24 & 0.98 & 39.6 \\
\hline 2. Chemical crops protection & 930 & 465 & 2.34 & 1.17 & 41.4 \\
\hline 3. Biological crops protection & 1221 & 573 & 3.07 & 1.47 & 40.5 \\
\hline 4. Nutrient complex $1^{*}$ & 1179 & 459 & 3.21 & 1.29 & 41.1 \\
\hline \multirow[t]{2}{*}{ 5. Nutrient complex $2^{* *}$} & 1455 & 465 & 3.76 & 1.29 & 40.3 \\
\hline & \multicolumn{5}{|c|}{ Nutrition background $2-\mathrm{N}_{15} \mathrm{P}_{15} \mathrm{~K}_{15}+$ biohumus $\left(250 \mathrm{~kg} \mathrm{ha}^{-1}\right)$} \\
\hline 1. Control & 1206 & 419 & 3.19 & 0.87 & 39.3 \\
\hline 2. Chemical crops protection & 1017 & 462 & 2.83 & 1.29 & 43.3 \\
\hline 3. Biological crops protection & 1218 & 333 & 2.64 & 0.75 & 41.1 \\
\hline 4. Nutrient complex $1^{*}$ & 1167 & 477 & 3.77 & 1.55 & 37.4 \\
\hline \multirow[t]{2}{*}{ 5. Nutrient complex $2^{* *}$} & 1386 & 456 & 3.77 & 1.23 & 39.4 \\
\hline & \multicolumn{5}{|c|}{ Nutrition background 3 - biohumus $\left(250 \mathrm{~kg} \mathrm{ha}^{-1}\right)$} \\
\hline 1. Control & 942 & 333 & 2.34 & 0.83 & 37.6 \\
\hline 2. Chemical crops protection & 945 & 393 & 2.34 & 0.97 & 39.1 \\
\hline 3. Biological crops protection & 834 & 465 & 2.51 & 1.45 & 37.9 \\
\hline 4. Nutrient complex $1^{*}$ & 1218 & 453 & 3.13 & 1.16 & 39.9 \\
\hline 5. Nutrient complex $2^{* *}$ & 918 & 405 & 2.13 & 0.96 & 38.4 \\
\hline
\end{tabular}


Tillering of spring barley variety Shidniy depending on the nutrient complex (2012-2014)

\begin{tabular}{|c|c|c|c|c|}
\hline \multirow{2}{*}{ Variant } & \multicolumn{2}{|c|}{ Number of stems (pc. per $\mathrm{m}^{2}$ ) } & \multicolumn{2}{|c|}{ The coefficient of tillering } \\
\hline & Total & Productive & Total & Productive \\
\hline & \multicolumn{4}{|c|}{ Nutrition background $1-\mathrm{N}_{30} \mathrm{P}_{30} \mathrm{~K}_{30}$} \\
\hline 1. Control & 907.5 & 563.0 & 2.54 & 1.38 \\
\hline 2. Chemical crops protection & 685.0 & 551.5 & 2.31 & 1.46 \\
\hline 3. Biological crops protection & 893.5 & 561.0 & 2.54 & 1.59 \\
\hline 4. Nutrient complex $1^{*}$ & 846.0 & 484.0 & 2.52 & 1.54 \\
\hline \multirow[t]{2}{*}{ 5. Nutrient complex $2^{* *}$} & 871.0 & 528.0 & 2.50 & 1.52 \\
\hline & \multicolumn{4}{|c|}{ Nutrition background $2-\mathrm{N}_{15} \mathrm{P}_{15} \mathrm{~K}_{15}+$ biohumus $\left(250 \mathrm{~kg} \mathrm{ha}^{-1}\right)$} \\
\hline 1. Control & 818.5 & 430.5 & 2.59 & 1.36 \\
\hline 2. Chemical crops protection & 877.5 & 603.0 & 2.57 & 1.77 \\
\hline 3. Biological crops protection & 850.0 & 486.0 & 2.50 & 1.43 \\
\hline 4. Nutrient complex $1^{*}$ & 690.0 & 426.0 & 2.46 & 1.52 \\
\hline \multirow[t]{2}{*}{ 5. Nutrient complex $2^{* *}$} & 764.0 & 461.5 & 2.51 & 1.52 \\
\hline & \multicolumn{4}{|c|}{ Nutrition background 3 - biohumus $\left(250 \mathrm{~kg} \mathrm{ha}^{-1}\right)$} \\
\hline 1. Control & 704.0 & 432.5 & 2.13 & 1.23 \\
\hline 2. Chemical crops protection & 678.5 & 495.0 & 2.13 & 1.45 \\
\hline 3. Biological crops protection & 721.0 & 433.5 & 2.34 & 1.41 \\
\hline 4. Nutrient complex $1^{*}$ & 667.0 & 388.5 & 2.45 & 1.43 \\
\hline 5. Nutrient complex $2^{* *}$ & 792.5 & 471.0 & 2.42 & 1.46 \\
\hline
\end{tabular}

Note: *seed treatment preparation rost-forte in a mixture of aminoacids complex and set of biologics, crop spraying in the tillering and earing stages of a mixture preparations rost-concentrate 15.7.7. + aminoacids complex + helatyn + microbiological system; ** seed treatment liquid biofertilizer aidar in a mixture of complex biologics and crop spraying at tillering and earing stages mixture of biofertilizer aydar and microbiological system.

When studying the effect of growth regulators on crop yield structure parameters of spring barley was found that on the mineral nutrition background the best results were obtained with the first nutrient complex. Ear length increased compared to controls by $1.5 \mathrm{~cm}$, the number of grains in the ear - on $3.2 \mathrm{pc}$., weight of 1000 grains - on $0.9 \mathrm{~g}$ (Table 3).

On the organic-mineral nutrition background was observed a similar situation.

Effect of nutrient complexes on parameters of crop yield structure of spring barley variety Shidniy (2012-2014)

\begin{tabular}{|c|c|c|c|c|c|c|}
\hline № & Variant & $\begin{array}{l}\text { Plant height } \\
\text { (cm) }\end{array}$ & $\begin{array}{l}\text { Ear length } \\
\quad(\mathrm{cm})\end{array}$ & $\begin{array}{l}\text { The number of } \\
\text { grains in the ear } \\
\text { (piece) }\end{array}$ & $\begin{array}{c}\text { Weight of } \\
1000 \text { grains } \\
(\mathrm{g})\end{array}$ & $\begin{array}{l}\text { Nature grain } \\
\qquad\left(\mathrm{g} \mathrm{l}^{-1}\right)\end{array}$ \\
\hline & & \multicolumn{5}{|c|}{ Nutrition background $1-\mathrm{N}_{30} \mathrm{P}_{30} \mathrm{~K}_{30}$} \\
\hline & Control & 59.9 & 8.1 & 18.9 & 48.6 & 586.9 \\
\hline & Chemical crops protection & 65.8 & 8.9 & 21.3 & 47.9 & 586.0 \\
\hline & Biological crops protection & 64.6 & 9.0 & 20.9 & 48.7 & 587.5 \\
\hline & Nutrient complex $1^{*}$ & 64.5 & 9.6 & 22.1 & 49.5 & 587.8 \\
\hline \multirow{2}{*}{\multicolumn{2}{|c|}{ 5. Nutrient complex $2^{* *}$}} & 63.8 & 8.6 & 20.3 & 48.4 & 589.3 \\
\hline & & \multicolumn{5}{|c|}{ Nutrition background $2-\mathrm{N}_{15} \mathrm{P}_{15} \mathrm{~K}_{15}+$ biohumus $\left(250 \mathrm{~kg} \mathrm{ha}^{-1}\right)$} \\
\hline & Control & 63.9 & 7.9 & 18.7 & 46.5 & 579.9 \\
\hline & Chemical crops protection & 62.9 & 9.1 & 20.8 & 47.1 & 581.5 \\
\hline & Biological crops protection & 61.5 & 9.2 & 21.2 & 47.4 & 579.7 \\
\hline & Nutrient complex $1^{*}$ & 64.2 & 10.1 & 22.1 & 47.9 & 581.9 \\
\hline \multirow{2}{*}{\multicolumn{2}{|c|}{ 5. Nutrient complex $2^{* *}$}} & 61.9 & 9.6 & 21.1 & 47.7 & 565.8 \\
\hline & & \multicolumn{5}{|c|}{ Nutrition background 3 - biohumus $\left(250 \mathrm{~kg} \mathrm{ha}^{-1}\right)$} \\
\hline & Control & 59.3 & 8.5 & 19.2 & 45.8 & 556.0 \\
\hline & Chemical crops protection & 62.8 & 8.6 & 19.8 & 47.2 & 588.1 \\
\hline & Biological crops protection & 59.5 & 8.8 & 20.6 & 47.1 & 567.7 \\
\hline & Nutrient complex $1^{*}$ & 60.7 & 8.9 & 21.1 & 46.3 & 571.9 \\
\hline & Nutrient complex $2^{* *}$ & 59.2 & 9.1 & 23.3 & 46.3 & 562.6 \\
\hline
\end{tabular}

Note: *seed treatment preparation rost-forte in a mixture of aminoacids complex and set of biologics, crop spraying in the tillering and earing stages of a mixture preparations rost-concentrate 15.7.7. + aminoacids complex + helatyn + microbiological system; ** seed treatment liquid biofertilizer aidar in a mixture of complex biologics and crop spraying at tillering and earing stages mixture of biofertilizer aydar and microbiological system. 
The organic nutrition background contributed to obtaining the best results the crop yield structure when using of the second nutrient complex. Ear length increased compared to controls by $0.6 \mathrm{~cm}$, the number of grains in the ear - on 4.1 pc., weight of 1000 grains - on $0.5 \mathrm{~g}$.

When comparing the two options for the protection of plants against pests and diseases, it was found that regardless of the background of nutrition the highest parameters of crop yield structure was achieved using biological crop protection (use of microbiological preparations to inoculate seeds and crop spraying).

Compare backgrounds nutrition shows that using organic and organic-mineral nutrition backgrounds contributed with the highest parameters of crop yield structure compared to the control using the options that have been studied.

The efficiency of nutrient complexes at the level of crop yield of spring barley variety Shidniy showed in the Table 4.

Table 4.

Crop yield of spring barley variety Shidniy depending on the nutrient complex (2012-2014)

\begin{tabular}{|c|c|c|c|c|c|c|}
\hline \multirow{2}{*}{ Variant } & \multicolumn{4}{|c|}{ Crop yield $\left(\mathrm{t} \mathrm{ha}^{-1}\right)$} & \multicolumn{2}{|c|}{ Increase of crop yield } \\
\hline & $\mathrm{I}$ & II & III & Average & $\mathrm{t} \mathrm{ha}^{-1}$ & $\%$ \\
\hline & \multicolumn{6}{|c|}{ Nutrition background $1-\mathrm{N}_{30} \mathrm{P}_{30} \mathrm{~K}_{30}$} \\
\hline Control & 2.17 & 2.19 & 2.17 & 2.17 & - & - \\
\hline Chemical crops protection & 2.73 & 2.87 & 2.43 & 2.67 & 0.45 & 20.7 \\
\hline Biological crops protection & 2.59 & 2.68 & 2.50 & 2.59 & 0.42 & 19.4 \\
\hline Nutrient complex $1^{*}$ & 2.50 & 2.66 & 2.72 & 2.63 & 0.46 & 21.2 \\
\hline \multirow[t]{2}{*}{ Nutrient complex $2^{* *}$} & 2.51 & 2.57 & 2.67 & 2.58 & 0.41 & 18.9 \\
\hline & \multicolumn{6}{|c|}{ Nutrition background $2-\mathrm{N}_{15} \mathrm{P}_{15} \mathrm{~K}_{15}+$ biohumus $\left(250 \mathrm{~kg} \mathrm{ha}^{-1}\right)$} \\
\hline Control & 2.09 & 1.76 & 1.99 & 1.95 & - & - \\
\hline Chemical crops protection & 2.26 & 2.51 & 2.69 & 2.49 & 0.54 & 27.7 \\
\hline Biological crops protection & 2.21 & 2.27 & 2.20 & 2.23 & 0.28 & 14.4 \\
\hline Nutrient complex $1^{*}$ & 2.99 & 2.92 & 2.64 & 2.85 & 0.90 & 46.2 \\
\hline \multirow[t]{2}{*}{ Nutrient complex $2^{* *}$} & 2.84 & 2.76 & 2.83 & 2.81 & 0.86 & 44.1 \\
\hline & \multicolumn{6}{|c|}{ Nutrition background 3 - biohumus $\left(250 \mathrm{~kg} \mathrm{ha}^{-1}\right)$} \\
\hline Control & 1.94 & 2.13 & 1.76 & 1.94 & - & - \\
\hline Chemical crops protection & 2.30 & 2.40 & 2.99 & 2.56 & 0.62 & 31.9 \\
\hline Biological crops protection & 2.66 & 2.79 & 2.69 & 2.71 & 0.77 & 39.7 \\
\hline Nutrient complex $1^{*}$ & 2.78 & 3.00 & 2.71 & 2.83 & 0.89 & 45.9 \\
\hline Nutrient complex $2^{* *}$ & 3.09 & 2.84 & 2.65 & 2.86 & 0.92 & 47.4 \\
\hline
\end{tabular}

Note: *seed treatment preparation rost-forte in a mixture of aminoacids complex and set of biologics, crop spraying in the tillering and earing stages of a mixture preparations rost-concentrate 15.7.7. + aminoacids complex + helatyn + microbiological system; ** seed treatment liquid biofertilizer aidar in a mixture of complex biologics and crop spraying at tillering and earing stages mixture of biofertilizer aydar and microbiological system. $\mathrm{LSD}_{05}, \mathrm{t}^{-1}$ : $\mathrm{A}-0.13, \mathrm{~B}-0.17, \mathrm{AB}-0.29$

On the mineral nutrition background the highest crop yield was obtained by using the first nutrient complex. Increase of compared with the control amounted $0.46 \mathrm{tha}^{-1}$.

Organic and mineral nutrition background, combined with the first nutrient complex of allowances contributed with crop yield of $0.90 \mathrm{t} \mathrm{ha}^{-1}$, compared with controls.

In organic nutrition background was obtained the highest parameters of crop yield. The largest increase $\left(0.92 \mathrm{t} \mathrm{ha}^{-1}\right)$ was obtained by using a second-nutrient complex.

The use of growth regulators, regardless of background power, contributed to the improvement economic efficiency parameters of spring barley growing (Table 5).

On mineral nutrition background using biological crop protection production cost of one ton of grain was the lowest, while net profit was higher than the control at 643.4 uah ha $^{-1}$.

The combination of organic-mineral nutrient background to the second nutrition complex of contributed to the increase the level of profitability on $40.3 \%$ compared with the control.

When comparing nutrition of backgrounds together, it was found that the most cost-effective was to use organic nutrition background.

\section{CONCLUSIONS}

Application of new nutrient complexes in combination with organic and organic-mineral nutrition background promotes the good growth and development of plants during the growing season that in turn provides the best parameters of crop yield structure, and consequently the crop yield of spring barley variety Shidniy in the condition of the Eastern Steppe of Ukraine.

The highest cost-effectiveness of spring barley growing was obtained by using a second nutrition complex of organic nutrition background (level of return was $70.3 \%$ ). 
The economic efficiency of new nutrient complexes (2012-2014)

\begin{tabular}{|c|c|c|c|c|c|c|c|c|c|}
\hline Variant & $\begin{array}{c}\text { Crop } \\
\text { yield } \\
\left(\mathrm{t} \mathrm{ha}^{-1}\right)\end{array}$ & $\begin{array}{c}\text { Increase } \\
\text { of } \\
\text { crop } \\
\text { yield } \\
\left(\mathrm{t} \mathrm{ha}^{-1}\right)\end{array}$ & $\begin{array}{c}\text { Cost of } \\
\text { crop } \\
\text { yield } \\
\text { (uah) }\end{array}$ & $\begin{array}{c}\text { Cost of } \\
\text { increase } \\
\text { of } \\
\text { crop } \\
\text { yield } \\
\text { (uah) }\end{array}$ & $\begin{array}{l}\text { Production } \\
\text { costs } \\
\left(\text { uah ha- }{ }^{-1}\right)\end{array}$ & $\begin{array}{l}\text { Including } \\
\text { additional } \\
\left(\text { uah ha }^{-1}\right)\end{array}$ & $\begin{array}{l}\text { Production } \\
\text { cost of } \\
1 \text { ton of } \\
\text { grain } \\
\text { (uah) }\end{array}$ & $\begin{array}{c}\text { Net } \\
\text { profit } \\
\left(\text { uah ha }^{-1}\right)\end{array}$ & $\begin{array}{c}\text { Level } \\
\text { of } \\
\text { profitability } \\
(\%)\end{array}$ \\
\hline & \multicolumn{9}{|c|}{ Nutrition background $1-\mathrm{N}_{30} \mathrm{P}_{30} \mathrm{~K}_{30}$} \\
\hline Control & 2.17 & - & 4340.0 & - & 3227.0 & - & 1487.1 & 1113.0 & 34.5 \\
\hline Chemical crops protection & 2.67 & 0.45 & 5340.0 & 900.0 & 3519.0 & 292.0 & 1318.0 & 1821.0 & 51.7 \\
\hline Biological crops protection & 2.59 & 0.42 & 5180.0 & 840.0 & 3308.6 & 81.6 & 1277.5 & 1871.4 & 56.6 \\
\hline Nutrient complex $1^{*}$ & 2.63 & 0.46 & 5260.0 & 920.0 & 3503.6 & 276.6 & 1332.2 & 1756.4 & 50.1 \\
\hline \multirow[t]{2}{*}{ Nutrient complex $2^{* *}$} & 2.58 & 0.41 & 5160.0 & 820.0 & 3428.6 & 201.6 & 1328.9 & 1731.4 & 50.5 \\
\hline & \multicolumn{9}{|c|}{ Nutrition background $2-\mathrm{N}_{15} \mathrm{P}_{15} \mathrm{~K}_{15}+$ biohumus $\left(250 \mathrm{~kg} \mathrm{ha}^{-1}\right)$} \\
\hline Control & 1.95 & - & 3900.0 & - & 3504.5 & - & 1797.2 & 395.5 & 11.3 \\
\hline Chemical crops protection & 2.49 & 0.54 & 4980.0 & 1080.0 & 3796.5 & 292.0 & 1524.7 & 1183.5 & 31.2 \\
\hline Biological crops protection & 2.23 & 0.28 & 4460.0 & 560.0 & 3586.1 & 81.6 & 1608.1 & 873.9 & 24.4 \\
\hline Nutrient complex $1^{*}$ & 2.85 & 0.90 & 5700.0 & 1800.0 & 3781.1 & 276.6 & 1326.7 & 1918.9 & 50.7 \\
\hline \multirow[t]{2}{*}{ Nutrient complex $2^{* *}$} & 2.81 & 0.86 & 5620.0 & 1720.0 & 3706.1 & 201.6 & 1318.9 & 1913.9 & 51.6 \\
\hline & \multicolumn{9}{|c|}{ Nutrition background 3 - biohumus $\left(250 \mathrm{~kg} \mathrm{ha}^{-1}\right)$} \\
\hline Control & 1.94 & - & 3880.0 & - & 3157.0 & - & 1627.3 & 723.0 & 22.9 \\
\hline Chemical crops protection & 2.56 & 0.62 & 5120.0 & 1240.0 & 3449.0 & 292.0 & 1347.3 & 1671.0 & 48.4 \\
\hline Biological crops protection & 2.71 & 0.77 & 5420.0 & 1540.0 & 3238.8 & 81.6 & 1195.1 & 2181.2 & 67.3 \\
\hline Nutrient complex $1^{*}$ & 2.83 & 0.89 & 5660.0 & 1780.0 & 3433.6 & 276.6 & 1213.2 & 2226.4 & 64.8 \\
\hline Nutrient complex $2^{* *}$ & 2.86 & 0.92 & 5720.0 & 1840.0 & 3358.6 & 201.6 & 1174.3 & 2361.4 & 70.3 \\
\hline
\end{tabular}

Note: *seed treatment preparation rost-forte in a mixture of aminoacids complex and set of biologics, crop spraying in the tillering and earing stages of a mixture preparations rost-concentrate 15.7.7. + aminoacids complex + helatyn + microbiological system; ** seed treatment liquid biofertilizer aidar in a mixture of complex biologics and crop spraying at tillering and earing stages mixture of biofertilizer aydar and microbiological system.

\section{REFERENCES}

Бурбела М. (1995): Сучасні агроекологічні і соціальні аспекти хімізації сільського господарства. Пропозиція. 1-3.

Cociu, A. I. (2012): Winter wheat yields and their stability in different crop rotation types and nitrogen fertilization regimes. Romanian Agriculture Research. 29: 139-148.

Доспехов Б. А. (1985): Методика полевого опыта. Б.А. Доспехов. М.: Агропромиздат. 336.

Jankowski, K. J.-Kijewski, L.-Dubis, B. (2015): Milling quality and flour strength of the grain of winter wheat grown in monoculture. Romanian Agriculture Research. 32: 191-200.

Кисіль В. І. (1997): Біологічне землеробство: тенденції в світі та позиція України. В.І. Кисіль. Вісн. аграрної науки. 10: 9-13.

Ковырялов Ю. П. (1989): Интенсивные технологии в растениеводстве. М.: Агропромиздат.

Лихочвор В. В. (2004): Агробіологічні основи формування врожаю озимої пшениці в умовах західного Лісостепу України: Дис. д-ра с.-г. наук: 06. 01. 09. Львівський держ. аграрний ун-т. Л.
Olofsson, S. (1993): Influence of preceding crop and crop residue on stand and yield of winter wheat (Triticum aestivum L.) in different tillage systems, including zero tillage. Uppsala. Crop Production Science.

Qin, R.-Stamp, P.-Richner, W. (2004): Impact of tillage on root systems of Winter Wheat. Madison. Agronomy Journal. 6: 1523-1530.

Rácz, I.-Kádár, R.-Moldován, V.-Has, I. (2015): Performance and stability of grain yield and yield components in some winter wheat varieties. Romanian Agriculture Research. 32: 11-18.

Shanahan, J. F.-Donelly, K. J.-Smith, D. H.-Smika, D. E. (1985): Shoot development properties associated with grain yield in Winter Wheat. Crop Science. 5: 770-775.

Sieling, K.-Gunther-Borstel, O.-Teebken, T. (1999): Soil mineral N and $\mathrm{N}$ net mineralization during autumn and winter under an oilseed rape-winter wheat-winter barley rotation in different crop management systems. J. Agr. Sci. 132. 2: 127-137.

Тараріко О. Г. (1999): Біологізація та екологізація грунтозахисного землеробства. Вісник аграрної науки. 10. 
